\title{
MODEL STUDENT TEAMS ACHIEVIEMENT DEVISION (STAD) BERPENDEKATAN SAITIFIK UNTUK MENINGKATKAN KEMAMPUAN KOGNITIF BIOLOGI SISWA SMA
}

\author{
Sumiyati Saleh ${ }^{1)}$, Bahtiar $^{2)}$, Ade Haerullah ${ }^{3)}$ \\ ${ }^{1)}$ Guru SMA Negeri 2 Kota Ternate \\ ${ }^{2)}$ 3) Dosen Program Studi Pendidikan BilogiFKIP Universitas Khairun \\ Email: sumiyati saleh9@gmail.com
}

\begin{abstract}
Abstrak
Model Student Teams Achieviement Devision (STAD) merupakan pembelajaran kooperatif yang sederhana, yang terdiri atas langkah utama yaitu: presentasi kelas, kerja tim, kuis, dan rekognisi tim. Penelitian ini bertujuan untuk mengetahui pengaruh model pembelajaran STAD terhadap kemampuan kognitif siswa di SMA Negeri 2 Kota Ternate pada materi berbagai tingkat keanekaragaman hayati di Indonesia beserta ancaman dan pelestariannya. Penelitian ini merupakan quasy eksperimen dengan rancangan Pretest-Posttes Nonequivalent Control Group. Populasi penelitian ini adalah siswa kelas X IPA, sementara populasi penelitian adalah peserta didik kelas X IPA1 dan X IPA2, dengan jumlah siswa masing-masing 25 orang. Teknik pengumpulan data yang digunakan adalah tes kemapuan (preetes dan posttes). Hasil uji anacova menunjukkan nilai sig. $0,000 \quad 0,05$, sehingga dapat disimpulkan bahwa penerapan model pembelajaran STAD berpendekatan saintifik berpengaruh secara signifikan terhadap kemampuan kognitif peserta didik.
\end{abstract}

Kata kunci: Model STAD, saintifik, kemampuan kognitif.

\section{PENDAHULUAN}

Pembelajaran dalam kurikulum 2013 diharapkan berorientasi pada pendekatan saintifik sehingga peserta didik menjadi lebih terlibat secara aktif dalam proses belajar mengajar melalui kegiatan mengamati, menanya, mengumpulkan data, mengasosiasikan, dan mengkomunikasikan. Pada umumnya pendekatan saintifik menuntut seorang guru untuk memahami dan memiliki kompetensi yang pedagogik dalam melaksanakan pembelajaran dikelas. Salah satu kemampuan pedagogik yang dimaksud adalah pemahaman terhadap strategi dan model pembelajaran yang berpusat pada peserta didik.

Model student teams achieviement devisions (STAD) merupakan pembelajaran kontruktivisme dan kooperatif cenderung melatih peserta didik menjadi pembelajar yang mandiri, bekerja sama dan bertanggungjawab terhadap teman satu kelompoknya agar mereka saling membelajarkan (Haerullah dan Hasan, 
2017). Selain itu model pembelajaran STAD merupakan pembelajaran kooperatif yang paling sederhana terdiri atas komponen utama yaitu menyampaikan tujuan, presentasi kelas, tim, kuis, dan rekognisi tim yaitu berupa pemberian sertifikat atau bentuk-bentuk penghargaan lainnya pada kelompok (Slavin, 2008).

Menurut Kurniasih dan Sani (2017) model pembelajaran STAD memiliki beberapa kelebihan diantaranya peserta didik dituntut untuk aktif sehingga peserta didik lebih percaya diri dan meningkatkan kecakapan individunya, Interaksi sosial akan nampak dalam kelompok sehingga peserta didik belajar dalam bersosialisasi dengan lingkungannya (kelompoknya). Di dalam kelompok, peserta didik diajarkan untuk membangun komitmen dalam mengembangkan kelompoknya, mengajarkan menghargai orang lain, saling percaya, dan saling mengerti dengan materi yang ada, sehingga peserta didik saling membantu dan mengurangi sifat kompetitif. Model ini memerlukan kemampuan khusus guru sebagai fasilitator, mediator, motivator dan evaluator (Isjoni, 2010). Menurut Ermawati (2014), implementasi pendekatan saintifik melalui model pembelajaran kooperatif STAD sebagai upaya meningkatkan aktivitas dan hasil belajar siswa SMA Negeri 9 Kota Bengkulu.

Berdasarkan hasil observasi awal terhadap pelaksanaan pembelajaran di SMAN 2 Kota Ternate khususnya kelas $X$ ditemukan bahwa proses pembelajaran masih terpusat pada guru (teacher centered) berdasarkan hasil wawancara dengan salah satu guru Biologi di SMAN 2 Kota Ternate diperoleh nilai rata-rata kemampuan kognitif ujian semester ganjil kelas X tahun ajaran 2015-2016 pada materi tingkat keanekaragaman hayati di Indonesia beserta ancaman dan pelestariannya adalah 65,25 sedangkan untuk tahun ajaran 2016 - 2017 untuk materi yang sama adalah 68,58 masih di bawah kriteria ketuntasan minimal yaitu 70. Menyadari belum tuntasnya kemampuan memecahkan masalah (problem solving) dan kemampuan kognitif peserta didik, menuntut guru melakukan perbaikan proses pembelajaran.

Selama ini umumnya guru hanya menyajikan pembelajaran pada materi tingkat keanekaragaman hayati beserta ancaman dan pelestariannya menggunakan metode ceramah dan pemberian tugas sehingga peserta didik kurang terlibat aktif dan tidak mendapatkan pengalaman belajar yang bermakna terutama pada kemampuan problem solving. Metode ceramah adalah cara mengajar yang harus diakui masih mempunyai peranan penting tetapi khusus untuk pelajaran eksakta, dalam hal ini Biologi, metode ceramah sama sekali tidak dapat diandalkan lagi menjadi satu satunya metode pengajaran (Faiji, 2013). Oleh karena itu, dalam proses pembelajaran guru perlu menggabungkan salah satu metode, strategi, 
dengan model yang relevan. Tanpa adanya kesempatan untuk berdiskusi, mengajukan pertanyaan, melakukan dan bahkan mengajarkan kepada orang lain, belajar yang sesungguhnya tidak akan terjadi (Silberman, 2013). Ketika peserta didik belajar bersama orang lain, peserta didik akan mendapatkan dukungan emosional dan intelektual dari teman mereka sehingga dapat meningkatkan motivasi belajar (Slavin, 2005).

\section{METODE PENELITIAN}

Jenis penelitian ini adalah quasy eksperimen dengan menggunakan rancangan pretest-posttes nonequivalent control group. Penelitian ini dilaksanakan pada bulan Oktober semester ganjil tahun pembelajaran 2018-2019 di SMA Negeri 2 Kota Ternate. Populasi penelitian ini adalah siswa kelas X IPA, sementara populasi penelitian adalah peserta didik kelas X IPA1 dan X IPA2, dengan jumlah siswa masing-masing 30 orang. Kelas X IPA1 diajarkan dengan menggunakan model pembelajaran STAD berpendekatan saintifik, sedang kelas X IPA2 diajarkan dengan model konvensional (teacher sentered, metode ceramah divariasi dengan tanya jawab). Instrumen yang digunakan dalam penelitian ini adalahsoal preetes dan soal postes dalam bentuk soal pilihan ganda sebanyak 10 butir soal dan soal uraian. Skor pretes dan postes kemampuan kognitif selanjutnya dianalisis dengan teknik analisis kuantitatif. Uji hipotesis menggunakan uji Anacova dengan bantuan Statistical Package for Social Sciense (SPSS) 20, yang diawali dengan uji homogenitas dan uji Anacova dengan taraf signifikansi 0,05.

\section{HASIL DAN PEMBAHASAN}

Hasil penelitian menunjukkan bahwa nilai rata-rata pretes kemampuan kognitif siswa pada pembelajaran model STAD adalah 34,45 dan model belajar konvensional adalah 34,38 . Nilai postes kemampuan kognitif siswa pada model STAD adalah 88,16 dan model konvensional adalah 76.45. Lebih jelasnya tentang nilai pretes dan postes kemampuan kognitif siswa pada model pembelajaran STAD dan model konvensional dapat dilihat pada gambar berikut. 


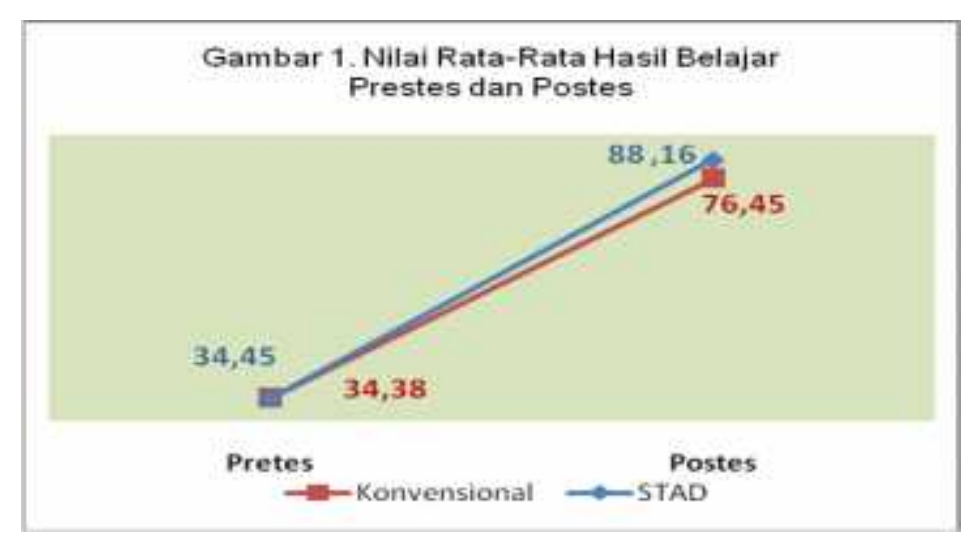

Gambar 1. di atas menunjukan bahwa nilai rata-rata postes kemampuan kognitif siswa dalam pembelajaran biologi pada model pembelajaran STAD lebih tinggi dibanding nilai rata-rata postes kemampuan kognitif siswa pada model konvensional. Data prestes kemapuan kognitif siswa pada kedua model pembelajaran relatif sama.

Uji homogenitas berguna untuk melihat apakah dua atau lebih kelompok data berasal dari populasi yang memiliki variansi yang sama. Uji homogenitas data dilakukan terhadap nilai rata-rata terkoreksi dari tiap kelompok data. Hasil uji homogenitas data pretes kemampuan kognitif siswa dengan menggunakan uji Levene diperoleh nilai sig. 0,126 dan postes diperoleh nilai sig. 0,586. Hal ini menunjukan bahwa baik data pretes maupun data postes kemampuan kognitif siswa memiliki sig. 0,05 sehingga dapat disimpulkan bahwa kedua kelompok data tersebut homogen. Hasil Uji homogenitas data kemampuan kognitif siswa dapat dilihat pada tabel berikut.

Tabel 1. Test of Homogeneity of Variances

\begin{tabular}{|l|r|r|r|r|}
\hline & Levene Statistic & \multicolumn{1}{c|}{ df1 } & df2 & \multicolumn{1}{c|}{ Sig. } \\
\hline Pretes_HB & 2.406 & 1 & 58 & .126 \\
Postes_HB & .299 & 1 & 58 & .586 \\
\hline
\end{tabular}

Normalitas data diuji dengan menggunakan statistik One Sample Kosmogrov-Semirnov. Kriteria pengujian normalitas data adalah jika nilai probabilitas (sig.) masing-masing variabel terikat yang diuji lebih besar dari nilai alpa yang digunakan $(0,05)$ maka Ho diterima, artinya tidak ada penyimpangan terhadap normalitas data variabel bebas, sehingga data tersebut dinyatakan 
berdistribusi normal. Hasil uji normalitas data pretes dan postes kemapuan kognitif siswa dapat dilihat pada tabel berikut.

Tabel 2. One-Sample Kolmogorov-Smirnov Test

\begin{tabular}{|ll|r|r|}
\hline & & Pretes_HB & \multicolumn{1}{|c|}{ Postes_HB } \\
\hline N & & 60 & 60 \\
& Mean & 33.8667 & 77.7833 \\
& Std. Deviation & & \\
& & 3.45168 & 4.09254 \\
Most Extreme Differences & Absolute & .165 & .106 \\
& Positive & .130 & .106 \\
Kolmogorov-Smirnov Z & Negative & -.165 & -.074 \\
& & 1.279 & .819 \\
Asymp. Sig. (2-tailed) & & .076 & .514 \\
& & & \\
\hline
\end{tabular}

a. Test distribution is Normal.

Berdasarkan uji normalitas data kemampuan kognitif siswa diperoleh nilai Asymp. sig. (2-tailed) untuk data pretes adalah 0,076 dan data postes adalah 0,514. Hal ini menunjukan Asymp. sig. (2-tailed) >0,05 maka dapat disimpulkan bahwa baik data pretes maupun data postes kemapuan kognitif siswa terdistribusi normal.

Hasil uji hipotesis pengaruh model pembelajaran STAD berpendekatan saintifik terhadap kemampuan kognitif siswa dalam pembelajaran biologi dengan menggunakan uji Anacova diperoleh nilai Sig. 0,000. Oleh karena nilai sig. $0,0000,05$ sehingga $\mathrm{H}_{0}$ di tolak dan $\mathrm{H}_{1}$ diterima, sehingga dapat disimpulkan bahwa ada pengaruh menggunakan model Student Teams Achieviement Devision $(S T A D)$ berpendekatan saintifik terhadap kemampuan kognitif siswa dalam pembelajaran biologi di SMA Negeri 2 Kota Ternate pada materi berbagai tingkat keanekaragaman hayati di Indonesia beserta ancaman dan pelestariannya. 
Tabel 3. Tests of Between-Subjects Effects

Dependent Variable:Postes_HB

\begin{tabular}{|l|r|r|r|r|r|}
\hline Source & $\begin{array}{c}\text { Type III Sum of } \\
\text { Squares }\end{array}$ & df & Mean Square & \multicolumn{1}{c|}{ F } & \multicolumn{1}{c|}{ Sig. } \\
\hline Corrected Model & $435.363^{\mathrm{a}}$ & 2 & 217.681 & 22.445 & .000 \\
Intercept & 2092.118 & 1 & 2092.118 & 215.713 & .000 \\
Pretes_HB & 222.546 & 1 & 222.546 & 22.946 & .000 \\
Model_Belajar & 208.579 & 1 & 208.579 & 21.506 & .000 \\
Error & 552.821 & 57 & 9.699 & & \\
Total & 364003.000 & 60 & & & \\
Corrected Total & 988.183 & 59 & & & \\
\hline
\end{tabular}

a. R Squared $=, 441$ (Adjusted R Squared $=, 421)$

Berdasarkan hasil analisa anacova menunjukan bahwa pembelajaran dengan menggunakan model STAD berpendekatan saintifik berpengaruh signifikan terhadap kemampuan kognitif siswa dalam pembelajaran biologi. Selain itu, nila rata-rata postes kemampuan kognitif siswa pada model STAD berendekatan saintifik pada kategori sangat baik $(88,16)$ sementara pembelajaran model konvensional pada kategori baik $(76,45)$. Hal ini disebabkan oleh model STAD menuntut setiap siswa untuk berperan aktif dalam pembelajaran sehingga rasa percaya diri, kecakapan individunya, dan interaksi sosial semakin berkembang (Kurniarsih dan Sani, 2017). Model pembelajaran STAD merupakan variasi pembelajaran kooperatif yang memacu peserta didik agar saling mendorong dan membantu satu sama lain untuk menguasai keterampilan yang diajarkan oleh guru. Model pembelajaran STAD didesain untuk memotivasi peserta didik supaya kembali bersemangat dan saling menolong untuk mengembangkan keterampilan yang diajarkan oleh guru.

Pada model STAD para siswa belajar dan beraktivitas sendiri untuk memperoleh pengalaman, pengetahuan tingkah laku serta mengembangkan ketrampilan yang bermakna. Model pembelajaran STAD berpendekatan saintifik dilaksanakan secara terstruktur dan sistematis dengan menggunakan kelompok kecil dengan jumlah anggota tiap kelompok anatar 4-5 orang, yang mempunyai latar belakang kemampuan akademik ,jenis kelamin, ras atau suku yang berbeda (heterogen). Langkah pembelajaran ini diawali dengan penyampaian tujuan pembelajaran, kemudian penyampaian materi, kegiatan kelompok dengan pendekatan saintifik, kuis dan penghargaan kelompok. Model pembelajaran ini 
efektif untuk membuat variasi suasana pola diskusi kelas, dimana siswa diberikan waktu lebih banyak untuk berpikir, merespon, dan saling membantu satu sama lain dalam kelompok (Trianto.2007).

Keunggulan model pembelajaran STAD yaitu siswa sebagai peserta didik lebih mampu mendengarkan, menerima, dan menghormati serta menerima orang lain, mampu meyakinkan dirinya untuk orang lain dan meyakinkan diri saling memahami. Hasil penelitian ini serupa temuan Maulana (2014) bahwa penerapan model pembelajaran $S T A D$ dapat meningkatkan hasil belajar kognitif siswa pada pembelajaran kimia sebesar 38\%. Dengan demikian, model STAD efektif untuk meningkatkan hasil belajar siswa. Berdasarkan hasil penelitian dari Wetapo dkk (2015) menyimpulkan bahwa siswa yang memperoleh pembelajaran model STAD dengan menggunakan bantuan matematika gasing mendapatkan hasil kognitif yang lebih baik dibandingkan dengan menggunakan model konvensional.

\section{SIMPULAN}

Berdasarkan hasil analisis data dan pembahasan di atas dapat disimpulkan bahwa model pembelajaran Student Teams Achievement Division (STAD) berpendekatan saintifik berpengaruh terhadap kemampuan kognitif peserta didik dalam pembelajaran biologi di SMA Negeri 2 Kota Ternate pada materi berbagai tingkat keanekaragaman hayati di Indonesia beserta ancaman dan pelestariannya.

\section{DAFTAR PUSTAKA}

Bloom, B.S. 1979. Taxonomy of Educational Objectives. Book I Cognitive Domain. London: Longman Group Ltd.

Dimiyati dan Mudjiono. 1994. Belajar dan Pembelajaran. Jakarta: Departemen Pendidikan dan Kebudayaan RI.

Haerullah, A. dan Hasan, S. 2017. Model dan Pendekatan Pembelajaran Inovatif. Lintas Nalar Yogyakarta.

Huda, M. 2013. Model -Model Pengajaran dan Pembelajaran. Yogyakarta: Pustaka Pelajar.

Isjoni. 2010. Kelebihan dan Kelemahan Model Student Teams Achievement Division (STAD). Bandung:Usaha Nasional.

Kurniarsih, I dan Sani, B. 2017. Ragam Pengembangan Model Pembelajaran. Kata Pena Jakarta.

Slavin, R.E. 2005. Educational Psychology Theory and Practice. Boston: Allyn Bacon 
Slavin, R.E. 2008. Cooperative Learning: Teori, Riset dan Praktik. Terjemahan oleh Nurulita. 2008. Bandung: Nusa Media.

Trianto. 2007. Model-model Pembelajaran Berorientasi Konstruktivistik (Konsep, Landasan Teoritis Praktis dan Implementasinya). Jakarta: Prestasi Pustaka Publisher. 